Article

\title{
Semisynthetic Cardenolides Acting as Antiviral Inhibitors of Influenza A Virus Replication by Preventing Polymerase Complex Formation
}

\author{
Laurita Boff ${ }^{1,2}$, André Schreiber ${ }^{1}$, Aline da Rocha Matos ${ }^{1,3}$, Juliana Del Sarto ${ }^{1,4}$, \\ Linda Brunotte ${ }^{1}$, Jennifer Munkert ${ }^{5}$, Flaviano Melo Ottoni ${ }^{4}{ }^{(}$, Gabriela Silva Ramos ${ }^{4}(\mathbb{D}$, \\ Wolfgang Kreis ${ }^{5}{ }^{\circledR}$, Fernão Castro Braga ${ }^{4}\left(\mathbb{0}\right.$, Ricardo José Alves ${ }^{4}$, Rodrigo Maia de Pádua ${ }^{4}$, \\ Cláudia Maria Oliveira Simões ${ }^{2, *}$ and Stephan Ludwig ${ }^{1}$ (D) \\ 1 Institute of Virology (IVM), Centre for Molecular Biology of Inflammation (ZMBE), \\ Westfaelische Wilhelms University (WWU), 48149 Münster, Germany; laurita.boff@hotmail.com (L.B.); \\ andre.schreiber@uni-muenster.de (A.S.); alinematos@hotmail.com (A.d.R.M.); \\ julianaldelsarto@gmail.com (J.D.S.); brunotte@uni-muenster.de (L.B.); ludwigs@uni-muenster.de (S.L.) \\ 2 Laboratory of Applied Virology, Department of Pharmaceutical Sciences, \\ Federal University of Santa Catarina (UFSC), Florianópolis, Santa Catarina 88040-900, Brazil \\ 3 Respiratory Viruses and Measles Laboratory, Oswaldo Cruz Institute, Fiocruz, \\ Rio de Janeiro 22775-051, Brazil \\ 4 Department of Pharmaceutical Sciences, Faculty of Pharmacy, Universidade Federal de Minas Gerais, \\ Belo Horizonte, Minas Gerais 31270-901, Brazil; fmottoni@hotmail.com (F.M.O.); \\ gabsramos@outlook.com (G.S.R.); fernao.braga@gmail.com (F.C.B.); dylancover@gmail.com (R.J.A.); \\ mpadua@hotmail.com (R.M.d.P.) \\ 5 Pharmaceutical Biology, Department of Biology, Friedrich-Alexander-University, \\ 91054 Erlangen-Nuremberg, Germany; jennifer.munkert@fau.de (J.M.); wolfgang.kreis@fau.de (W.K.) \\ * Correspondence: claudia.simoes@ufsc.br
}

Academic Editor: Claudio Frezza

Received: 27 September 2020; Accepted: 20 October 2020; Published: 21 October 2020

\begin{abstract}
Influenza virus infections represent a major public health issue by causing annual epidemics and occasional pandemics that affect thousands of people worldwide. Vaccination is the main prophylaxis to prevent these epidemics/pandemics, although the effectiveness of licensed vaccines is rather limited due to the constant mutations of influenza virus antigenic characteristics. The available anti-influenza drugs are still restricted and there is an increasing viral resistance to these compounds, thus highlighting the need for research and development of new antiviral drugs. In this work, two semisynthetic derivatives of digitoxigenin, namely C10 (3ß-((N-(2-hydroxyethyl)aminoacetyl)amino-3-deoxydigitoxigenin) and C11 (3 $\beta$-(hydroxyacetyl)amino-3-deoxydigitoxigenin), showed anti-influenza A virus activity by affecting the expression of viral proteins at the early and late stages of replication cycle, and altering the transcription and synthesis of new viral proteins, thereby inhibiting the formation of new virions. Such antiviral action occurred due to the interference in the assembly of viral polymerase, resulting in an impaired polymerase activity and, therefore, reducing viral replication. Confirming the in vitro results, a clinically relevant ex vivo model of influenza virus infection of human tumor-free lung tissues corroborated the potential of these compounds, especially C10, to completely abrogate influenza A virus replication at the highest concentration tested $(2.0 \mu \mathrm{M})$. Taken together, these promising results demonstrated that C10 and C11 can be considered as potential new anti-influenza drug candidates.
\end{abstract}

Keywords: semisynthetic cardenolides; anti-influenza; mechanism of action; polymerase activity inhibition 


\section{Introduction}

Influenza viruses cause annual epidemics and occasional pandemics that affect thousands of people worldwide, thus representing a major public health concern [1]. Influenza viruses belong to the Orthomyxoviridae family, and based on their antigenic characteristics, they were subdivided into four genera: A, B, C, and D [2,3], but only A and B are clinically relevant to humans [4]. In addition, Influenza A viruses (IAVs) were further classified according to their surface glycoproteins: hemagglutinin (HA) and neuraminidase (NA) [5].

Influenza viruses contain an eight segmented negative-sense, single-stranded viral RNA genome that encodes for at least eleven essential viral proteins. Each RNA segment is encapsulated into a ribonucleoprotein (RNP) molecule, consisting of the nucleoprotein (NP) and a trimeric RNA-dependent RNA polymerase (RdRp) complex composed by PA, PB1, and PB2 [6]. Inside the nucleus, the RdRp carries out transcription and replication using the vRNA as a template for both transcription to mRNA and synthesis of complementary RNA (cRNA) that serves as the template for novel vRNAs. During the infection, the synthesis of mRNAs occurs prior to cRNA and vRNA transcription, which are then exported out of the nucleus for the synthesis of the viral proteins [7].

Although vaccination is the main prophylactic strategy used to decrease the impact of annual influenza epidemics [8,9], the effectiveness of licensed vaccines is rather limited due to the high mutation rate of the influenza virus genome that alters antigenic characteristics [10]. Thus, influenza vaccines need to be revised every year. Based on data gathered from north and south hemispheres, a scientific committee meets twice a year to define the influenza virus strains that will be included in the vaccine composition to be administered in the next flu season [11]. However, in case of a pandemic, vaccines have to be produced ad hoc and are generally available only some months after the emergence and spread of the new pandemic virus [12].

Additionally, anti-IAV drugs, such as M2 ion channel inhibitors (adamantane derivatives: rimantadine and amantadine, no longer recommended since 2004-2005 due to high resistance rates) and neuraminidase inhibitors (NAIs: oseltamivir and zanamivir), have been used worldwide. However, the emergence of influenza virus strains resistant to these drugs has been reported increasingly [13-18]. Because of the lack of effective antivirals, there are many new drug development programs all over the world. In Russia and China, a cell fusion inhibitor, named umifenovir, is clinically used $[19,20]$. Other NAIs (laninamivir and peramivir) were recently introduced in the pharmaceutical markets of Japan, China, South Korea, and USA for influenza prevention and control, but they do not seem to be more effective than oseltamivir. Thus, influenza treatment with these drugs cannot be considered satisfactory [10], and the development of new anti-influenza drugs with different mechanisms of action is a real need. Intending to reach this goal, recently two drugs that inhibit functions of the viral polymerase, baloxavir marboxil and favipiravir, have been licensed in specific markets (the first one in Japan and USA, and the second solely in Japan), but only for special groups of patients [21-23]. Based on the data available so far, these new drugs should be only considered for emergency use since baloxavir caused a high rate of resistance in clinical trials, whereas favipiravir was shown to be teratogenic [10]. Based on these facts, research and development (R\&D) of new anti-influenza drugs remain valid and imperative.

Cardenolides are cardiac glycosides (CGs) mainly found in plant species of Apocynaceae (e.g., Nerium oleander L.) and Plantaginaceae (e.g., Digitalis lanata Ehrh. and D. purpurea L.) families [24], which have been broadly used for over 200 years to treat several cardiac conditions, including congestive heart failure, arrhythmias, and cardiogenic shock [25-27]. Therapeutically, the most relevant cardenolides are digoxin and digitoxin. Their mechanism of action and selectivity are mainly related to the direct inhibition of $\mathrm{Na}^{+} / \mathrm{K}^{+}$-ATPase $\alpha$-subunit, which promotes cardiac muscle contraction [28].

In recent years, these compounds have been investigated for the treatment of other pathological conditions, such as viral infections. Their potential antiviral activity against a wide variety of viruses has been reported, such as adenovirus [29], chikungunya virus [30], 
coronavirus [31-33], cytomegalovirus [34-36], dengue virus [37], herpes virus [38-41], HIV [42-44], human papillomavirus [45], influenza virus [46-48], and respiratory syncytial virus [49].

Even though many studies have shown the potent antiviral activity of CGs, only three [46-48] focused on influenza viruses. Hoffmann et al. [46] reported that ouabain and lanatoside $C$ reduced IAV and Influenza B virus (IBV) replication (strains A/WSN/33 (H1N1) and B/Yamagata/88, respectively) by regulating $\mathrm{Na}^{+}$currents. Kiyohara et al. [47] showed that a CG isolated from the "desert rose" (Adenium obesum) reduced $>50 \%$ viral titers of the IAV strain A/PR8/34 (H1N1). Likewise, Amarelle et al. [48] demonstrated that ouabain inhibited the protein translational machinery via a decrease of intracellular $\mathrm{K}^{+}$.

In this context, 16 new semisynthetic cardenolide derivatives of digitoxigenin (C6a, C6b, C6c, $\mathrm{C} 6 \mathrm{~d}, \mathrm{C7a}, \mathrm{C7b}, \mathrm{C7c}, \mathrm{C7d}, \mathrm{C} 9, \mathrm{C10}, \mathrm{C11}, \mathrm{C12}, \mathrm{C13}, \mathrm{C14}, \mathrm{C15}$, and C16) were produced and preliminarily screened for anti-herpes activity as well as for cytotoxic effects against several human cancer cell lines [50]. Furthermore, the cytotoxic effects of some derivatives on H460 lung cancer cells were deeply investigated using different methodological approaches [51]. We also reported a proposal for the mechanism of anti-herpes action of $\mathbf{C 1 0}$ and C11, which interfered with the intermediate and final steps of HSV replication, but not with the early stages since they completely abolished the expression of the UL42 ( $\beta)$ and gD $(\gamma)$ proteins and partially reduced that of ICP27 ( $\alpha)$; additionally, they were not virucidal and had no prophylactic effects [41].

In the present study, the anti-influenza virus effects of the same 16 new cardenolide derivatives were evaluated. Since two of them showed the most significant inhibitory potential on viral replication, namely C10 (3ß-((N-(2-hydroxyethyl)aminoacetyl)amino-3-deoxydigitoxigenin) and C11 (3ß-(hydroxyacetyl)amino-3-deoxydigitoxigenin), the main goal of this work was to explore their antiviral mechanism by using different in vitro and ex vivo methodological strategies. In this sense, $\mathbf{C 1 0}$ and $\mathbf{C 1 1}$ could be considered as promising candidates to be further evaluated for the treatment of influenza virus infections.

\section{Results}

\subsection{Anti-Influenza Virus Activity of Cardenolide Derivatives}

Firstly, 17 compounds (16 new semisynthetic cardenolide derivatives (C6a to C16) and digitoxigenin that was used as scaffold for the semisynthesis) were screened, at $1 \mu \mathrm{M}$, for their antiviral activity against IAV (strain A/WSN/33 (H1N1), multiplicity of infection (MOI) 0.01, $24 \mathrm{~h}$ ) on A549 cells (Figure 1A). These compounds reduced viral titers at distinct levels, and those that reduced $>50 \%$ of viral titers (digitoxigenin, C7c, C10, C11, and C12) were selected for further assays. A similar antiviral profile was observed when Madin-Darby canine kidney (MDCK) cells were used (Figure 1B). It is important to note that compounds $\mathbf{C 1 0}$ and $\mathbf{C 1 1}$ showed the highest reduction of influenza virus titers, when compared to the other compounds on both cell lines.

Furthermore, all compounds were screened against a broader panel of IAV and IBV strains (seasonal IAV H3N2 (Panama/2007/1999), H7N7 (Seal/Mass/1-SC35M/80), H1N1pdm (Hamburg/04/2009), and IBV (Lee/40)). They were also very active against all viral strains tested (Figure S1-Supplementary Materials). 
(A)

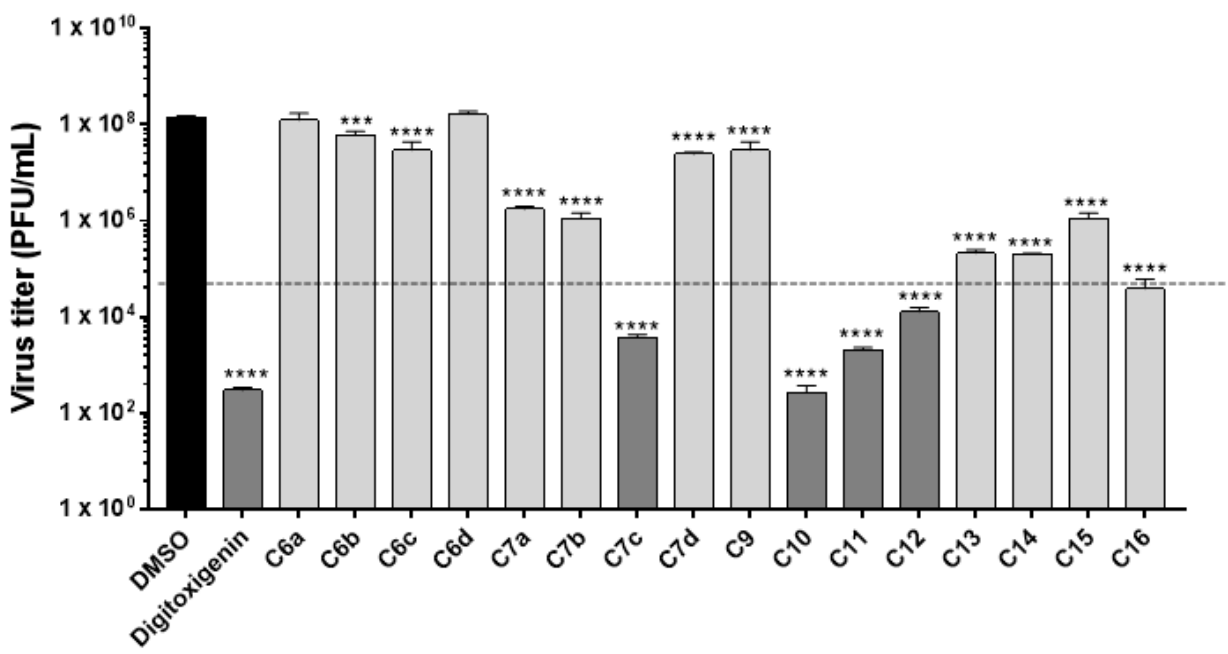

(B)

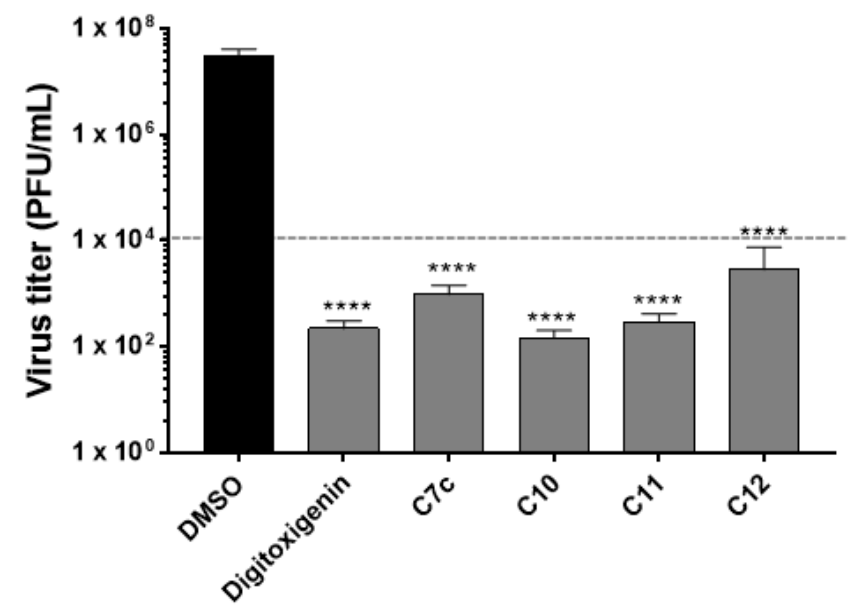

Figure 1. (A) Antiviral activity of new cardenolide derivatives (C6a, C6b, C6c, C6d, C7a, C7b, C7c, C7d, C9, C10, C11, C12, C13, C14, C15, and C16) and the scaffold digitoxigenin against influenza A virus (strain A/WSN/33 (H1N1)). A549 cells were infected at MOI 0.01 for $1 \mathrm{~h}$ and further treated with $1 \mu \mathrm{M}$ of the compounds. Supernatants were collected at $24 \mathrm{~h}$ post-infection (p.i.) and titrated on Madin-Darby canine kidney (MDCK) cells. The black line indicates the compounds that reduced $>50 \%$ of viral titer. Dimethyl sulfoxide (DMSO) served as solvent control and the titers of DMSO-treated cells were arbitrarily set to $100 \%$. (B) Antiviral activity of the most active compounds in the preliminary screening (digitoxigenin, C7c, C10, C11, and C12) using the same experimental conditions cited above for (A) on MDCK cells. ${ }^{* * *} p<0.001$ and ${ }^{* * *} p<0.0001$ vs. DMSO, one-way ANOVA, post hoc test Dunnet.

\subsection{Cardenolide Derivatives Effects on Cell Viability and Influenza Replication}

Since digitoxigenin and compounds C7c, C10, C11, and C12 were shown to be the most active in the preliminary screenings, their cytotoxicity was evaluated on A549 and MDCK cells. None of them reduced cell viability at concentrations at least five times higher than the concentrations used in the initial screenings (Table 1). This evaluation ensured that the compounds would not act indirectly by simply reducing cell viability but rather act directly on virus propagation by interfering with certain stages of their replication cycle. For all compounds, $\mathrm{IC}_{50}$ and $\mathrm{CC}_{50}$ values as well as selectivity indices (SI) against IAV (strain A/WSN/33 (H1N1)) were calculated (Table 1). Compounds C10 and C11 were the most potent against IAV replication presenting $\mathrm{IC}_{50}$ values of approximately $0.06 \mu \mathrm{M}$ on both cell lines. They showed SI values of 226 and 161 on A549 cells; and 306 and 241 on MDCK cells, respectively. 
Based on these favorable results, compounds $\mathbf{C 1 0}$ and C11, whose chemical structures are depicted in Figure 2, were selected to further explore their antiviral mechanisms of action.

Table 1. Cytotoxicity and antiviral activity of compounds C7c, C10, C11, C12, and digitoxigenin against influenza A virus (strain WSN/33 (H1N1)) replication on A549 and MDCK cells.

\begin{tabular}{|c|c|c|c|c|c|c|}
\hline \multirow{2}{*}{ Compounds } & \multirow{2}{*}{$\begin{array}{l}\text { A549 Cells } \\
C_{50}(\mu \mathrm{M})\end{array}$} & \multicolumn{2}{|c|}{ IAV (Strain WSN/33 (H1N1)) } & \multirow{2}{*}{$\begin{array}{c}\text { MDCK Cells } \\
\mathrm{CC}_{50}(\mu \mathrm{M})\end{array}$} & \multicolumn{2}{|c|}{ IAV (Strain WSN/33 (H1N1)) } \\
\hline & & $\mathrm{IC}_{50}(\mu \mathrm{M})$ & SI & & $\mathrm{IC}_{50}(\mu \mathrm{M})$ & SI \\
\hline C7c & $9.398 \pm 0.741$ & $0.125 \pm 0.010$ & 75.282 & $22.170 \pm 2.393$ & $0.103 \pm 0.009$ & 216.166 \\
\hline $\mathrm{C} 10$ & $12.790 \pm 0.754$ & $0.057 \pm 0.002$ & 226.052 & $18.343 \pm 0.915$ & $0.060 \pm 0.004$ & 306.164 \\
\hline C11 & $10.025 \pm 0.962$ & $0.062 \pm 0.000$ & 161.645 & $15.983 \pm 0.235$ & $0.066 \pm 0.006$ & 241.379 \\
\hline $\mathrm{C} 12$ & $13.280 \pm 1.753$ & $0.123 \pm 0.013$ & 107.647 & $23.340 \pm 1.184$ & $0.091 \pm 0.008$ & 257.483 \\
\hline Digitoxigenin & $6.465 \pm 1.004$ & $0.070 \pm 0.010$ & 92.366 & $6.360 \pm 0.427$ & $0.072 \pm 0.005$ & 88.052 \\
\hline
\end{tabular}

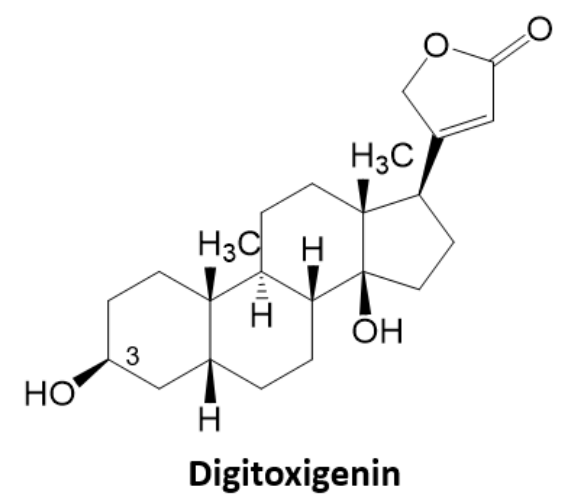

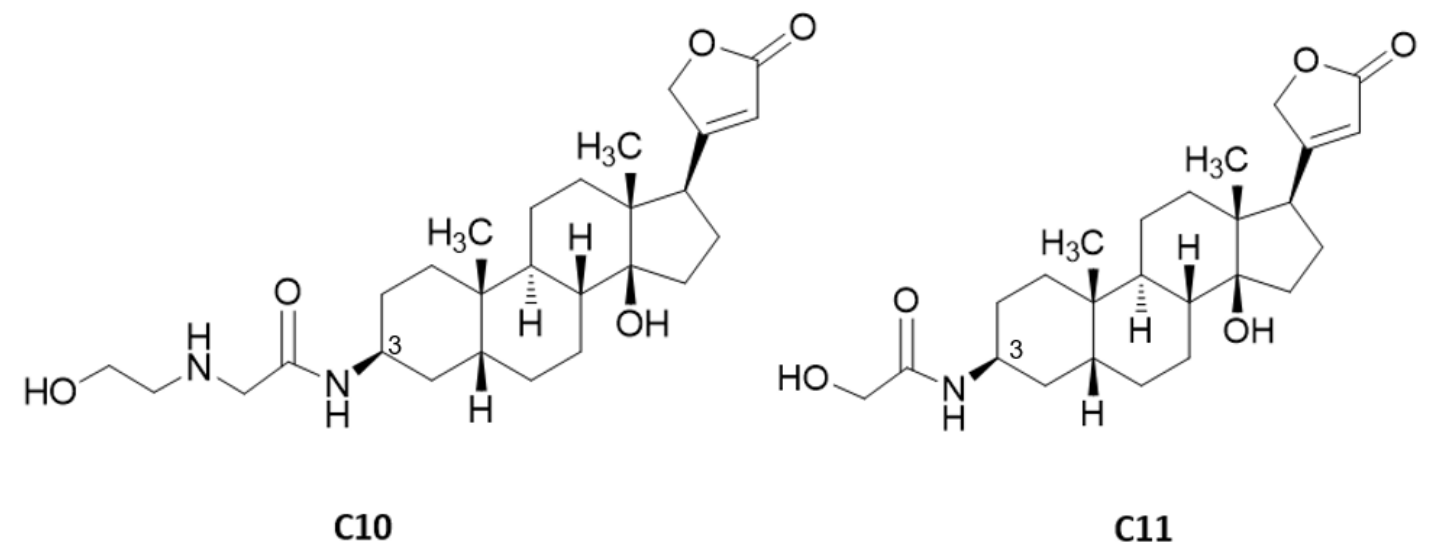

Figure 2. Chemical structures of digitoxigenin, $\mathbf{C 1 0}$, and $\mathbf{C 1 1}$ derivatives.

\subsection{Anti-Influenza Virus Mechanism of Action of Compounds C10 and C11}

2.3.1. C10 and C11 Affect the Expression of Viral Proteins at the Earlier Stages of Influenza A Virus Replication Cycle

The elucidation of the antiviral mechanism of action of $\mathbf{C 1 0}$ and $\mathbf{C 1 1}$ against IAV (A/WSN/33 (H1N1)) started by investigating the viral protein accumulation at different stages within the first replication cycle (Figure 3). Both compounds decreased early (NS1, NP, and PB1) and late viral protein expression (M1) when compared to the positive control (MDCK cells infected but not treated), at all 
time periods tested. Compound C10 was most effective to reduce protein expression. In addition, impaired viral protein expression was already clearly observed at the earliest time point analyzed $(2 \mathrm{~h}$ post-infection (p.i.)), demonstrating action of the compounds in very early stages of the replication cycle.

(A)

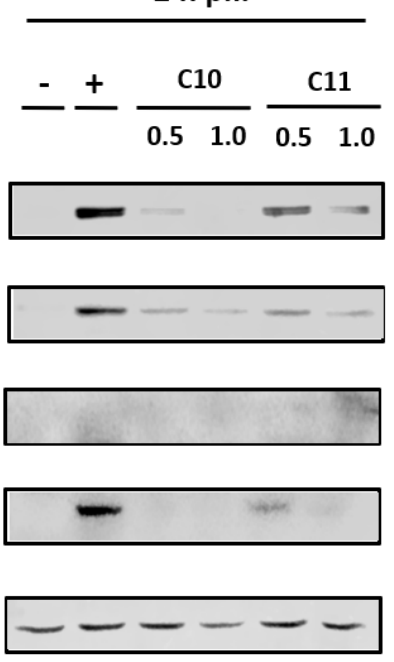

$6 \mathrm{~h} \mathrm{p.i.}$
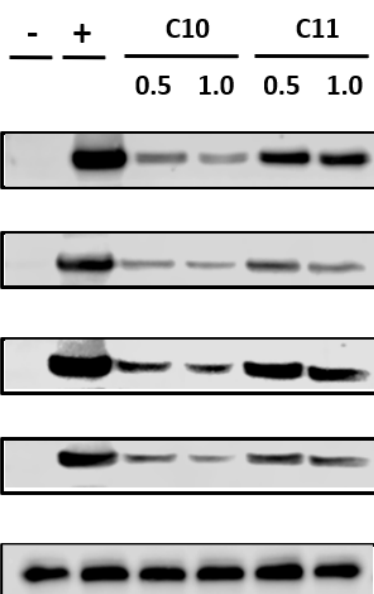

8 h p.i.

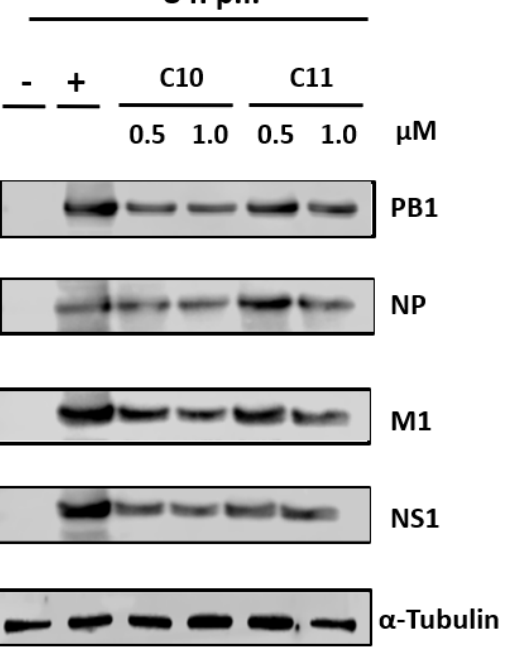

(B)
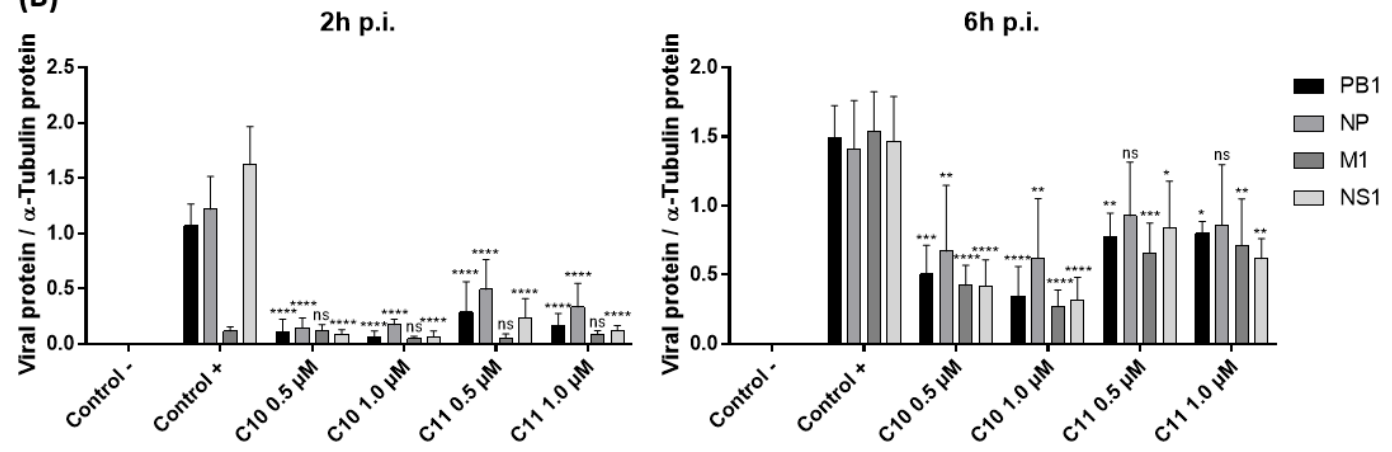

$6 \mathrm{~h}$ p.i.

8h p.i.

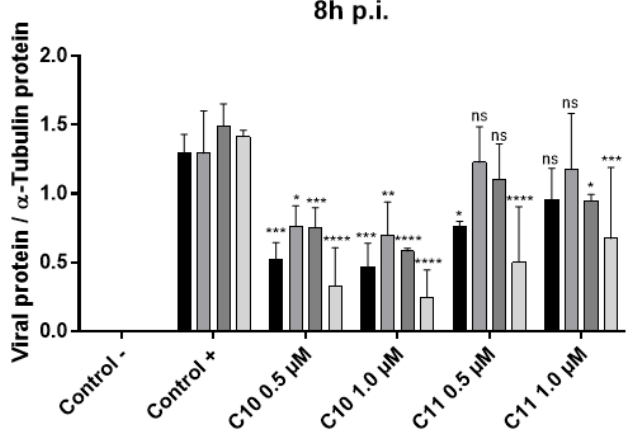

Figure 3. (A) Effects of $\mathbf{C 1 0}$ and $\mathbf{C 1 1}$ on influenza A virus (strain A/WSN/33 (H1N1)) protein expression over time. Western blot analysis occurred of MDCK cells infected at MOI 5 and then treated with both compounds $(0.5$ and $1.0 \mu \mathrm{M})$. Cell lysates were collected 2,6 , and $8 \mathrm{~h}$ post-infection (p.i.), run on SDS-PAGE $10 \%$, and analyzed using specific antibodies for viral (PB1, nucleoprotein (NP), M1, and NS1) proteins. Equal protein loading was confirmed by probing for $\alpha$-Tubulin. MDCK cells not infected or treated were used as negative control (-). MDCK cells infected and just DMSO-treated (solvent control) were used as positive control (+). (B) The graph indicates the ratio of each viral protein to $\alpha$-Tubulin protein (ns = no significant, ${ }^{*} p<0.05 ;{ }^{* *} p<0.01$; ${ }^{* * *} p<0.001$; and ${ }^{* * * *} p<0.0001$ vs. the respective viral controls, two-way ANOVA, post hoc test Dunnet). 
To analyze whether the interference of $\mathbf{C 1 0}$ and $\mathbf{C 1 1}$ with virus replication already occurs on the transcriptional level, the mRNA levels of influenza NP (segment 5) and M1 (segment 7) were quantified at $6 \mathrm{~h}$ p.i. Additionally, the amounts of newly produced cRNA and vRNA of the segments 5 and 7 were quantified (Figure 4). In agreement with the previous results, C10 and C11 decreased viral mRNA levels. Once again, C10 presented the higher potency to reduce mRNA levels of both segments, when compared to the control group, especially for M1. As expected, a similar outcome was observed for cRNA and vRNA levels, with more pronounced differences after C10 treatment.
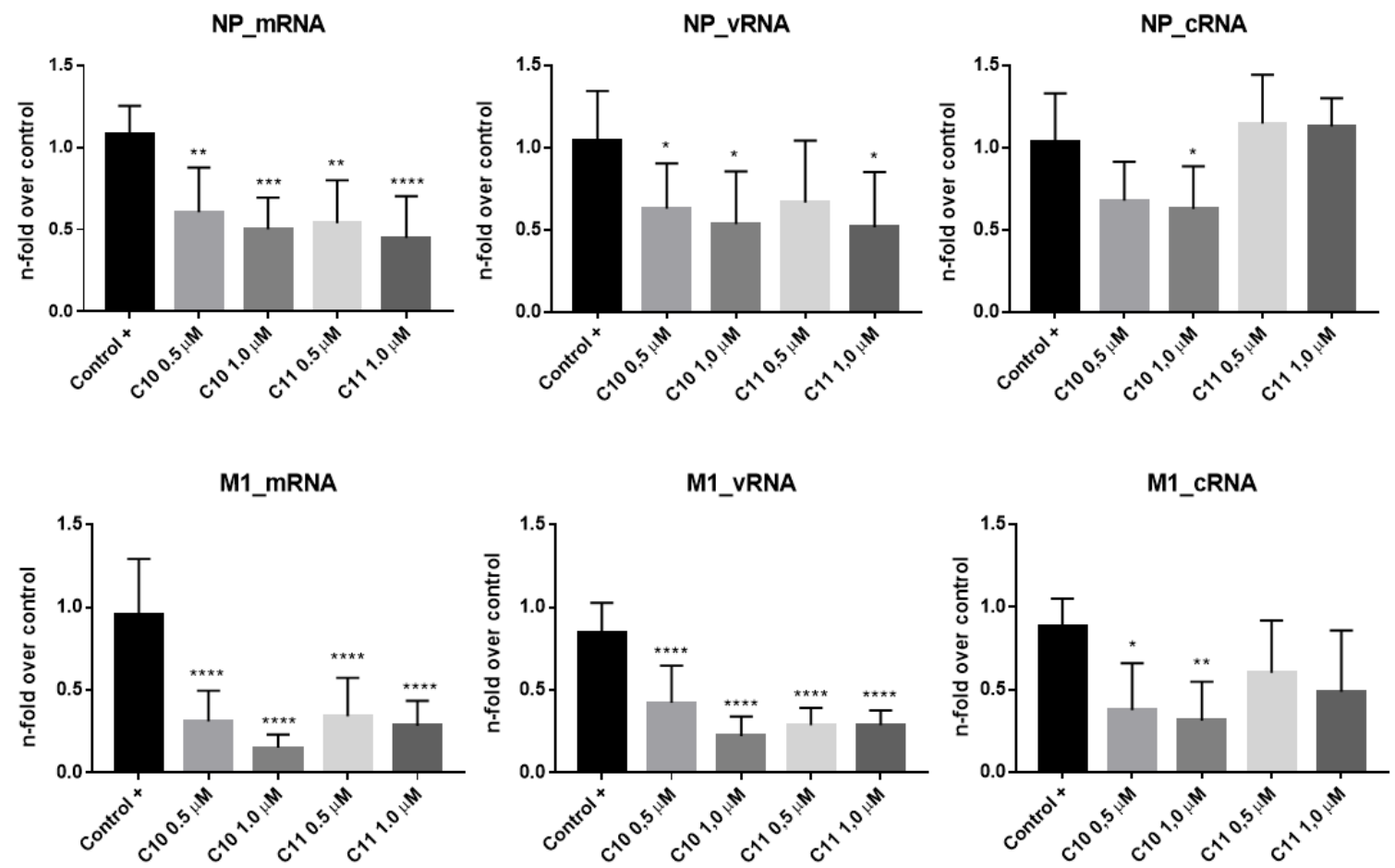

Figure 4. Effects of $\mathbf{C 1 0}$ and $\mathbf{C 1 1}$ on influenza A virus RNA transcription (strain A/WSN/33 (H1N1)). MDCK cells were infected at MOI 5 and then treated with both compounds $(0.5$ and $1.0 \mu \mathrm{M})$ for $6 \mathrm{~h}$. Total RNA was extracted and viral mRNA, vRNA, and cRNA of NP (segment 5) and M1 (segment 7) were analyzed by qRT-PCR using glyceraldehyde 3-phosphate dehydrogenase (GAPDH) as the housekeeping gene. MDCK cells infected and just DMSO-treated (solvent control) were used as positive control (+). ${ }^{*} p<0.05$; $^{* *} p<0.01,{ }^{* * *} p<0.001$ and ${ }^{* * *} p<0.0001$ vs. the respective viral controls, one-way ANOVA, post-hoc test Dunnet.

Altogether, these results demonstrate that both compounds act at early stages of the IAV replication cycle by reducing the transcription of viral mRNA, leading to impaired synthesis of new viral proteins and, consequently, the production of new virions.

\subsubsection{C10 and C11 Affect the Polymerase Complex}

To understand if the decrease of RNA levels was due to direct effects on viral polymerase, the activity of IAV polymerase after treatment with $\mathbf{C 1 0}$ and C11 was investigated using a plasmid-based mini genome polymerase assay. MDCK cells were transfected with plasmids expressing the constituents of the viral polymerase, PB1, PB2, PA, and NP, along with a plasmid that generates a viral RNA template expressing luciferase under control of the viral RNA promoters (Figure 5A). In this assay, the treatment diminished the polymerase activity as well. Noteworthy, the highest concentration of $\mathbf{C 1 0}(1.0 \mu \mathrm{M})$ decreased the polymerase activity by $>50 \%$. While $\mathbf{C 1 1}$ again was less potent and showed no significant reduction at the lowest concentration tested $(0.5 \mu \mathrm{M})$, the compound still resulted in approximately $40 \%$ decrease of polymerase activity at $1.0 \mu \mathrm{M}$ (Figure $5 \mathrm{~A}$ ). 
(A)

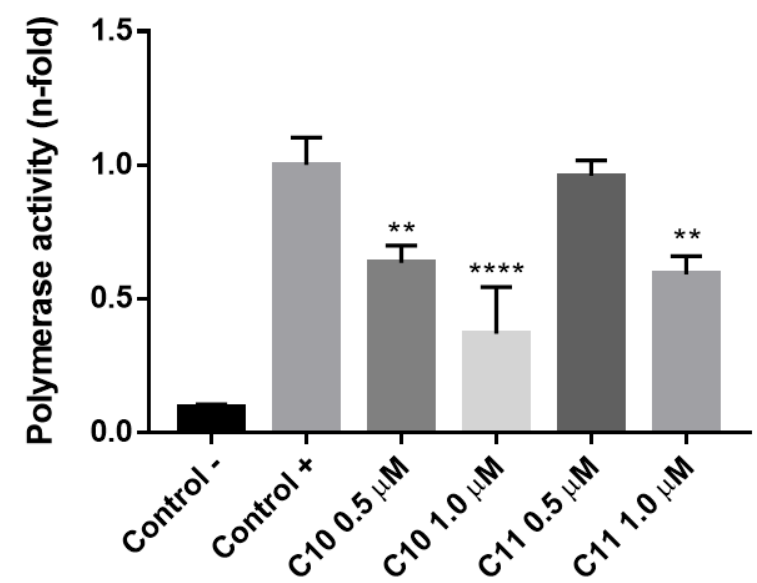

(B)
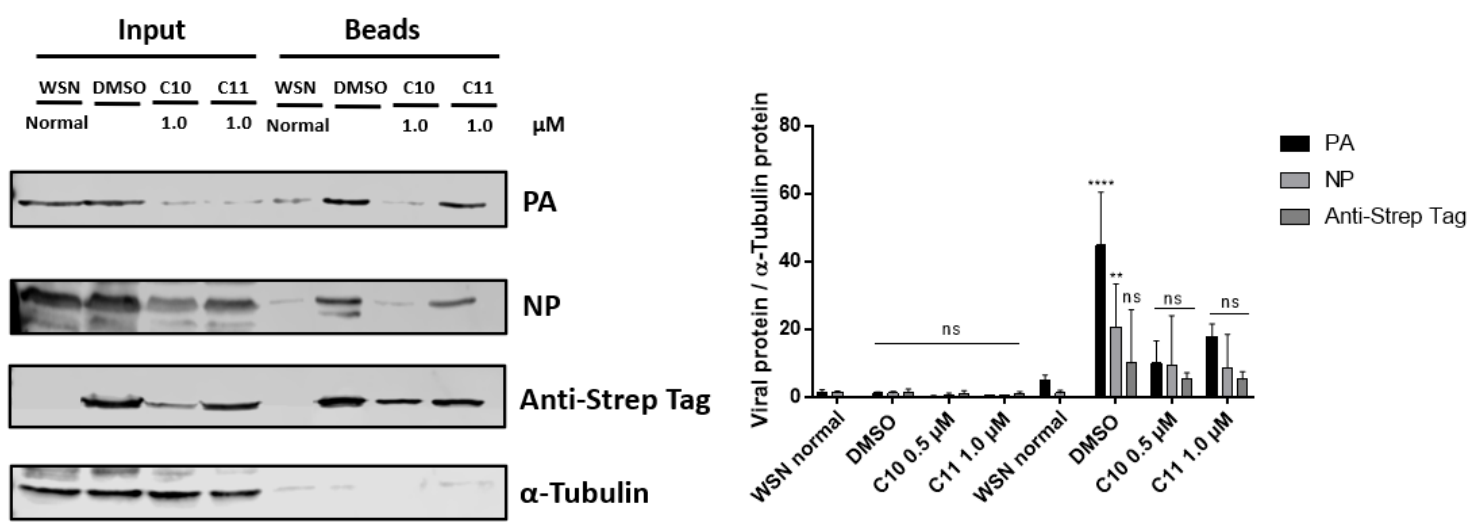

Figure 5. Effects of $\mathbf{C} 10$ and $\mathrm{C} 11$ on influenza A virus polymerase activity. (A) MDCK cells were transfected with plasmids expressing PB1, PB2, PA, and NP (PPPN), along with a plasmid-encoding luciferase under control $(+)$ of viral promoter sequences. As negative control (-), the transfection mix lacking the PB2-encoding plasmid (PPN) was used. Medium was changed $4 \mathrm{~h}$ post-transfection (p.t.), C10 and C11 were added at 0.5 and $1.0 \mu \mathrm{M}$ and incubated. After $24 \mathrm{~h}$ p.t., cells were lysed and the results were calculated as n-fold of luciferase activity in PPN-transfected C10 and C11-treated cells, which was arbitrarily set to 1 , and represent the mean \pm SD of three independent experiments. ${ }^{* *} p<0.01$ and ${ }^{* * * *} p<0.0001$ vs. positive control, one-way ANOVA, post hoc test Dunnet. (B) Effects of $\mathbf{C 1 0}$ and $\mathbf{C 1 1}$ cardenolide derivatives on recombinant influenza A virus (Strep-PB2-WSN) protein expression, when bound or not to beads. Subcellular fractions were added to the beads and incubated overnight at $4{ }^{\circ} \mathrm{C}$. After, beads were pelleted and Western blot analyses were performed using specific antibodies polymerase complex (PA, PB1, NP, Anti-Strep TagM1, and NS1) proteins. Equal protein loading was confirmed by probing for $\alpha$-Tubulin. WSN normal $=$ cells infected with influenza A virus $(($ strain $\mathrm{A} / \mathrm{WSN} / 33(\mathrm{H} 1 \mathrm{~N} 1))$ and not treated; DMSO = solvent control. The graph indicates the ratio of each viral protein to $\alpha$-Tubulin protein (ns $=$ no significant, ${ }^{* *} p<0.01$, and ${ }^{* * * *} p<0.0001$ vs. the respective viral controls, two-way ANOVA, post hoc test Dunnet).

Next, to explore if $\mathbf{C 1 0}$ and C11 were interfering with the assembly of the polymerase complex subunits, cells were infected with a recombinant IAV strain (Strep-PB2-WSN/H1N1) bearing a Strep-tag at the PB2 segment [52]. This allows specific precipitation of the polymerase complex containing vRNPs to analyze subunit composition.

The results demonstrated that both compounds, but more pronouncedly $\mathbf{C 1 0}$, interfered with the viral polymerase complex assembly, since PA, PB1 and NP amounts were strongly decreased in the 
complex precipitates (Figure 5B). Accordingly, it can be concluded that antiviral action occurred due to the interference in the assembly of viral polymerase complex resulting in a deficient polymerase activity and, therefore, reduced viral replication.

\subsubsection{C10 and C11 Reduce Viral Replication in an Ex Vivo Model of Human Lung Tissue}

Finally, to evaluate antiviral activity of C10 and C11 in a more clinically relevant model of influenza virus infection, the compounds were tested in an ex vivo tumor-free human lung tissue explant model [53]. At $48 \mathrm{~h}$ p.i., C10 reduced the viral titers by 4 logs at the lowest concentration tested $(0.5 \mu \mathrm{M})$ and completely abrogated viral replication at the higher concentrations tested $(1.0$ and $2.0 \mu \mathrm{M})$ (Figure 6). At the same time, C11 abolished viral replication only at the highest concentration tested $(2.0 \mu \mathrm{M})$. Additionally, viability assay was performed with the treated lung tissues and confirmed that C10 did not reduce tissue integrity up to $48 \mathrm{~h}$ p.i. In contrast, C11 showed tissue toxicity at $48 \mathrm{~h}$ p.i. (>2-fold over control) (Figure S2-Supplementary Materials).
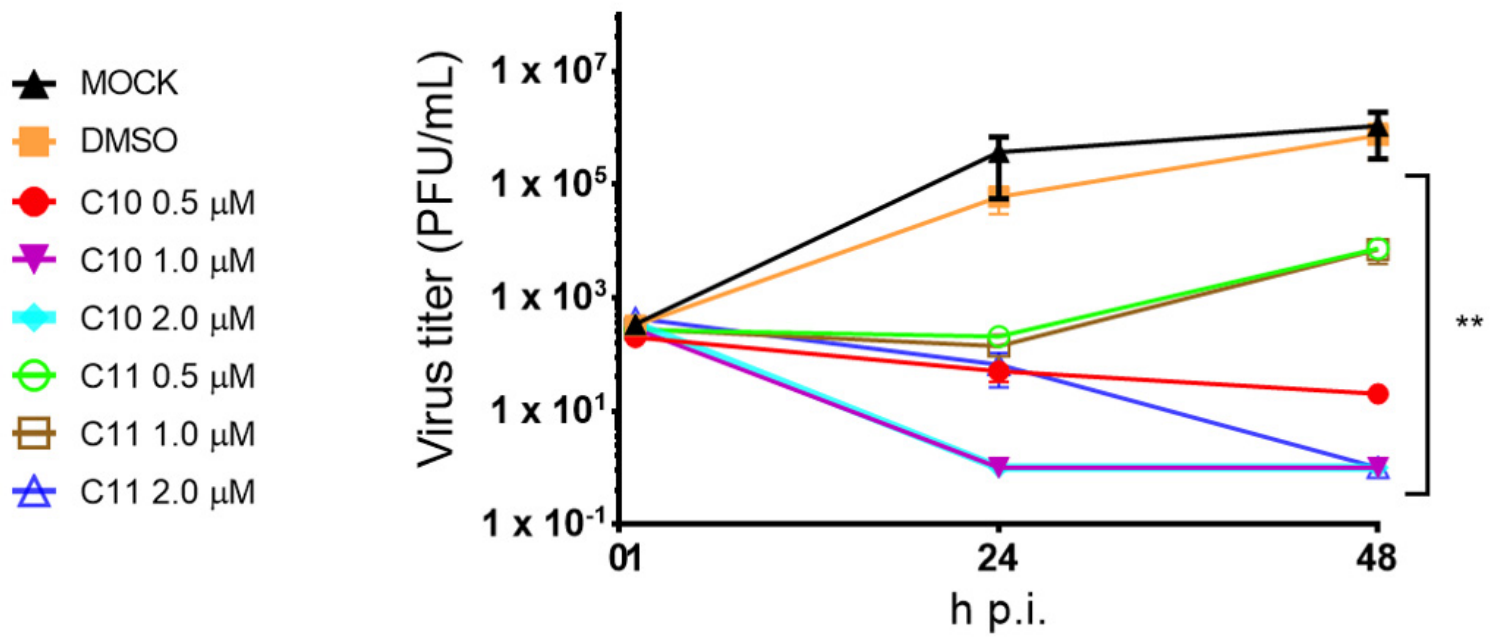

Figure 6. Effects of C10 and C11 on influenza A virus (A/Panama/2007/1999 (H3N2)) replication using an ex vivo human tumor-free lung model. Tissues were infected with $1 \times 10^{5}$ plaque-forming units (PFU)/mL of this recombinant virus for $1 \mathrm{~h}$ and further treated with both compounds $(0.5,1.0$, and $2.0 \mu \mathrm{M}$ ) for $48 \mathrm{~h}$. Tissue supernatants were collected at 1, 24, and $48 \mathrm{~h}$ post-infection (p.i.) and titrated on MDCK cells. Each time point represents mean $( \pm \mathrm{SD})$ of four independent experiments. ** $p<0.01$ vs. MOCK, two-way ANOVA, post hoc test Dunnet.

\section{Discussion}

Cardenolides are molecules clinically used to treat heart diseases, such as heart failure, arrhythmias, and cardiogenic shock [25-27]. However, several studies have suggested promising effects for the treatment of other diseases [54], including those caused by viral infections [29-49]. Even though CGs have been investigated against many viruses, little is known about their potential anti-influenza activity. The available data support an anti-influenza activity in vitro [46-48] and in vivo using rodents that express a $\mathrm{Na}^{+} / \mathrm{K}^{+}$-ATPase $\alpha 1$ resistant to GC [48]. Therefore, the evaluation of new semisynthetic cardenolides is a valid strategy to identify new antiviral drugs against influenza virus infection.

The anti-influenza screening performed herein with the 16 new semisynthetic derivatives of digitoxigenin disclosed compounds $\mathrm{C} 10$ and $\mathrm{C11}$ as the most potent ones with low $\mathrm{IC}_{50}$ values (ranging from 0.057 to $0.062 \mu \mathrm{M}$ on A549 cells and 0.060 to $0.066 \mu \mathrm{M}$ on MDCK cells, respectively), along with the highest SI values (ranging from 161 to 306, Table 1). As described by Boff et al. [50], digitoxigenin was used as scaffold for the semisynthesis of the derivatives cited above, and it was the most cytotoxic compound on A549 and MDCK cells, while presenting similar $\mathrm{IC}_{50}$ values to those of $\mathbf{C 1 0}$ and C11. These results showed digitoxigenin as the tested compound with the 
lowest SI value, whilst C10 and C11 disclosed the highest SI values. A previous report showed that the cardenolide oleandrigenin- $\beta$-D-glucosyl $(1 \rightarrow 4)-\beta$-D-digitalose, isolated from Adenium obesum (desert rose), presented anti-influenza activity since it reduced IAV titer (strain A/PR/8/34) on MDCK cells with an $\mathrm{IC}_{50}$ value of $0.86 \mu \mathrm{g} / \mathrm{mL}(=1.14 \mu \mathrm{M})$ [47]. It should be noted that this value is 19/17-fold higher than those here reported for $\mathrm{C10}$ and C11, respectively.

Our research group has recently described that both compounds inhibited $\mathrm{Na}^{+} / \mathrm{K}^{+}$-ATPase [50] and, therefore, this modulation function [55] might explain one of the mechanisms by which C10 and C11 interfere with influenza virus replication. The inhibition of $\mathrm{Na}^{+} / \mathrm{K}^{+}$-ATPase in host cells infected with influenza viruses caused by ouabain and lanatoside $C$ has been already demonstrated by other research groups [46,56]. Recently, it was reported that ouabain decreased the intracellular $\mathrm{K}^{+}$on A549 cells that is required for normal viral protein synthesis, and consequently reduced IAV replication due to $\mathrm{Na}^{+} / \mathrm{K}^{+}$-ATPase inhibition. Such a finding was confirmed in vivo by the inhibition of protein translation and the increased survival of influenza A/WSN/33-infected mice [48].

Both C10 and C11 demonstrated strong anti-influenza properties already manifested in the earlier stages of viral replication cycle. A significant reduction of viral proteins expression, such as PB1, NP, and NS1, was observed within only $2 \mathrm{~h}$ p.i. In accordance with this finding, C10 and C11 treatment also induced a decrease of viral mRNA levels, as they exemplarily demonstrated for segments 5 (NP) and 7 (M1). Furthermore, significant decreases in cRNA and vRNA levels were also detected. Altogether, these results suggest these compounds cause a general malfunction of the viral RNA-dependent RNA polymerase (RdRp), affecting its activity, which is involved in the synthesis of all three RNA species [57,58]. Indeed, the mini genome reporter gene assay employed herein indicated a decrease of the polymerase activity after treatment with both $\mathbf{C 1 0}$ and $\mathbf{C 1 1}$, when compared to the positive control (Figure 5A).

The IAV polymerase complex is composed of PB1, PB2, and PA, that together with NP and vRNA, form the vRNP complex. For the proper function of the polymerase, a correct assembly of the polymerase subunits is required. In this study, it was demonstrated that both $\mathbf{C 1 0}$ and $\mathbf{C 1 1}$ interfered with the polymerase complex assembly since levels of the polymerase constituents (PA, PB1, and NP) decreased after the Strep-tag pulldown of PB2.

To continue studying $\mathbf{C 1 0}$ and C11, the next step should be the investigation using an in vivo model to assess the promising antiviral effects already revealed in vitro. It is important to note that often in vivo studies are firstly done in non-human animals, such as mice or rats [59]. Nevertheless, the use of rodent models, even those xenotransplanted, is not advisable for this class of compounds, the cardenolides, since rodent cells are approximately 1000 times more resistant than human cells to the action of these compounds. Such difference can be explained because the main cellular target of cardenolides, the $\mathrm{Na}^{+} / \mathrm{K}^{+}$-ATPase enzyme, is expressed at different levels in humans and rodents [60,61]. Recently, Amarelle et al. [48] published a study using mice genetically modified to express $\mathrm{Na}^{+} / \mathrm{K}^{+}$-ATPase alpha 1 subunit, as occurs in humans, which can be an interesting approach to study cardenolides in vivo.

However, the use of an ex vivo model can be more robust and a viable economical alternative, simulating a bridge between in vitro and in vivo experiments and highlighting the non-use of laboratory animals. In this sense, an explant tumor-free human lung model provides a unique opportunity to analyze influenza viral replication in the complexity of human lung tissues that is as close to a real human infection scenario as possible. Since the lungs are the natural targets of these viruses, this model is extremely relevant for the investigation of potential new anti-influenza drugs.

Previously, it has been shown that an ex vivo infection is suitable for the evaluation of potential anti-influenza drugs and immunomodulatory agents. This model induced a complex innate immune response following the infection with the recombinant IAV (A/Panama/2007/1999 (H3N2)), which was manifested by a relevant expression of antiviral restriction factors, pro-inflammatory cytokines, interferons (IFNs) types I, II, and III, and a unique pattern of IFN- $\alpha$ subtypes. In this study, the macrolide antibiotic bafilomycin A (BafA) was applied to inhibit viral replication in lung tissues, 
and the pre-treatment with this drug for $1 \mathrm{~h}$ abolished IAV replication [53]. Complementarily, Weinheimer et al. [62] had already been shown that lung explants support the replication of diverse IAV strains.

Herein, the promising ex vivo results confirmed the in vitro findings demonstrating that when the human lung tissues were infected with the same recombinant IAV cited above, and treated with C10 $(1 \mu \mathrm{M})$ and C10 and C11 $(2 \mu \mathrm{M})$, they reduced significantly the viral titers below the detection limit. Noteworthy, C10 did not induce any relevant tissue toxicity, thus emphasizing its potential for further studies.

C10 and C11 also interfered with the assembly of viral polymerase resulting in a deficient polymerase activity. Such a mechanism can be the main antiviral action found herein for both compounds, and as far as we know, it has not been reported for any other CG. There are some recent studies reporting the inhibitory activity of influenza polymerase of different compounds, such as 5-(5-fluoro-1H-pyrrolo ((2,3-b)pyridin-3-yl)pyrazin-2(1H)-one derivatives [63], JL-5001 [64], R151785 [65], and for this reason, they are being called next-generation therapeutic agents.

\section{Materials and Methods}

\subsection{Compounds, Cell Lines and Viruses}

The semisynthesis and structure determination of new 16 cardenolide derivatives tested herein (C6a, C6b, C6c, C6d, C7a, C7b, C7c, C7d, C9, C10, C11, C12, C13, C14, C15, and C16) were carried out as previously described by Boff et al. [50]. Starting from digitoxigenin, $3 \beta$-azido-3-deoxydigitoxigenin was synthesized. Out of this intermediate compound, the two new series were prepared containing either glycosylated triazoles, obtained through click chemistry with propargyl glycosides (series i: C6a, C6b, C6c, C6d, C7a, C7b, C7c, and C7d), or compounds substituted in the alpha carbonyl position with different amines (series ii: C9, C10, C11, C12, C13, C14, C15, and C16). The structure of all new derivatives was verified by ${ }^{13} \mathrm{C}-\mathrm{NMR}$ and ${ }^{1} \mathrm{H}-\mathrm{NMR}$ [50].

Adenocarcinomic human alveolar basal epithelial cells (A549) and Madin-Darby canine kidney type II cells (MDCK-II) were cultivated in Dulbecco's modified Eagle's Medium (DMEM) and Eagle's minimum essential medium (MEM) (Sigma-Aldrich, St. Louis, MO, USA), respectively, both supplemented with 10\% fetal bovine serum (FBS) (Merck, Darmstadt, Germany) and 1\% penicillin/streptomycin (P/S) at $37^{\circ} \mathrm{C}$ and $5 \% \mathrm{CO}_{2}$ in humidified conditions.

Regarding the viruses tested, A/Hamburg/04/2009 (H1N1pdm09) was kindly provided by German National Reference Centre for Influenza (Brunhilde Schweiger, Robert-Koch Institute, Berlin, Germany). Recombinant A/Seal/Mass/1-SC35M/80 (H7N7) (SC35M), A/WSN/33 (H1N1) (WSN) and B/Lee/40 were generated from plasmids by using the bidirectional pHW2000 reverse genetics system [66]. Recombinant IAV strain A/Panama/2007/1999 (H3N2) was generously provided by Thorsten Wolff (Robert-Koch Institute, Germany), and recombinant Strep-PB2-A/WSN/33 was kindly supplied by Martin Schwemmle (University of Freiburg, Germany). Viruses were propagated on A549 and MDCK cells for $72 \mathrm{~h}$ and viral titers were determined by standard plaque assay on MDCK cells $[67,68]$.

\subsection{Anti-Influenza Screening}

The anti-influenza screening was performed as previous described by Schreiber et al. [69]. Briefly, $2.5 \times 10^{5}$ A549 or MDCK cells per well (12-well plates) were seeded and infected (MOI 0.01) for $30 \mathrm{~min}$ at $37^{\circ} \mathrm{C}$. Viruses were diluted in infection phosphate-buffered saline (PBS) (PBS supplemented with $1 \% \mathrm{P} / \mathrm{S}, 0.2 \%(v / v)$ Bovine Serum Albumin (BSA) 35\%, $0.01 \% \mathrm{MgCl}_{2}, 0.01 \% \mathrm{CaCl}_{2}$ ). Following, cells were washed with PBS and treated with the compounds (digitoxigenin, C6a, C6b , C6c, C6d, C7a, C7b, C7c, C7d, C9, C10, C11, C12, C13, C14, C15, and C16) at $1 \mu$ M diluted in infection DMEM or MEM (DMEM for A549 cells and MEM for MDCK cells, both supplemented with 1\% P/S, $0.2 \%$ $(v / v)$ BSA $35 \%, 0.01 \% \mathrm{MgCl}_{2}, 0.01 \% \mathrm{CaCl}_{2}$ ). Extemporaneously, $0.15 \mu \mathrm{g}$ TPCK-treated trypsin were added, and supernatants were harvested after $24 \mathrm{~h}$ incubation. Confluent MDCK cell monolayers 
(6-well plates) were infected with 10-fold dilution series of virus supernatants for $30 \mathrm{~min}$ at $37^{\circ} \mathrm{C}$. Then, virus inoculum was replaced by plaque medium $\left(14.2 \%(v / v) 10 \times \mathrm{MEM}, 0.3 \%(v / v) \mathrm{NaHCO}_{3}\right.$ (7.5\%), 0.014\% (v/v) DEAE-dextran (1\%), $1.4 \%(v / v) 100 \times \mathrm{P} / \mathrm{S}, 0.3 \%(v / v)$ BSA (35\%), $0.01 \%(v / v) \mathrm{CaCl}_{2}$ $(1 \%), 0.01 \%(v / v) \mathrm{MgCl}_{2}(1 \%), 0.9 \%(v / v)$ Agar (3\%), and extemporaneously $0.15 \mu \mathrm{g}$ TPCK-treated trypsin). Cells were then incubated for $72 \mathrm{~h}$ at $37^{\circ} \mathrm{C}(\mathrm{IAV})$ or $33^{\circ} \mathrm{C}(\mathrm{IBV})$, and viral plaques were counted. Only for the compounds that reduced $>50 \%$ of viral titers (digitoxigenin, C7c, C10, C11, and C12), the $\mathrm{IC}_{50}$ values were calculated (concentration of each compound that reduced viral replication by $50 \%$ ), by nonlinear regression of concentration-response curves.

\subsection{Cytotoxicity Evaluation}

A549 and MDCK cells were seeded in 96-well plates and grown overnight. Cells were treated with different concentrations of digitoxigenin, C7c, C10, C11, and C12 (5.0, 2.5, 1.25, 0.625, 0.313, 0.156, and $0.078 \mu \mathrm{M}$ ) or dimethyl sulfoxide (DMSO) $(0.1 \%)$, diluted in $100 \mu \mathrm{L}$ of DMEM or MEM, respectively, for $24 \mathrm{~h}$ at $37^{\circ} \mathrm{C}$ and $5 \% \mathrm{CO}_{2}$. Next, $15 \mu \mathrm{L}$ of sterile water or Triton $\mathrm{X}-10010 \%$ (CytoSelect $^{\mathrm{TM}} \mathrm{LDH}$ Cytotoxicity Assay Kit) were added to each well in DMEM or MEM, for $10 \mathrm{~min}$, at room temperature. Supernatants were collected and stored at $-80^{\circ} \mathrm{C}$ until used. Supernatants $(90 \mu \mathrm{L})$ were transferred to clean 96-well plates and $10 \mu \mathrm{L}$ of LDH Reagent (CytoSelect ${ }^{\mathrm{TM}}$ LDH Cytotoxicity Assay Kit) were added to each sample and incubated for $20 \mathrm{~min}$. Quantification was performed using a spectrophotometer at $405 \mathrm{~nm}$. The concentration of each sample that reduced cell viability by $50 \%$ was estimated as $\mathrm{CC}_{50}$.

\subsection{Anti-Influenza Viral Mechanism of Action}

\subsubsection{Western Blot Analyses}

To evaluate whether $\mathbf{C 1 0}$ and $\mathbf{C 1 1}$ interfere with viral or cellular protein expression, western blotting experiments were performed. In brief, cells were infected with IAV (A/WSN/33/H1N1) or were transfected with a recombinant IAV (Strep-PB2-WSN/H1N1) [52]. After that, cells were treated with each compound, washed with PBS, and lysed in radioimmunoprecipitation (RIPA) buffer (25 mM Tris- $\mathrm{HCl}$ (pH 8), $137 \mathrm{mM} \mathrm{NaCl}, 10 \%$ glycerol, $0.1 \%$ SDS, $0.5 \%$ sodium deoxycholate, $1 \% \mathrm{NP}-40$, and $2 \mathrm{mM}$ EDTA (pH 8)). RIPA protein lysates were cleared by centrifugation $\left(220 \times g, 4{ }^{\circ} \mathrm{C}, 10 \mathrm{~min}\right)$, mixed with $5 \times$ Laemmli buffer, separated by SDS-PAGE $10 \%$, blotted onto nitrocellulose membranes, and blocked with TBS-T buffer (50 mM Tris- $\mathrm{HCl}(\mathrm{pH} 7.5), 150 \mathrm{mM} \mathrm{NaCl}$, and $0.2 \%$ Triton X-100 supplemented with $3 \%$ BSA $(w / v))$. After blocking, membranes were incubated overnight with polyclonal anti-influenza A (IAV) PB1 (GeneTex, EUA), polyclonal anti-IAV PA (GeneTex, EUA), polyclonal anti-IAV NP (GeneTex, EUA), polyclonal anti-IAV M1 (GeneTex, EUA), polyclonal anti-IAV NS1 (GeneTex, EUA), monoclonal anti-Tubulin (T6199, Sigma-Aldrich, EUA), and monoclonal anti-Strep Tag (GT661, Sigma-Aldrich, EUA), all diluted in blocking buffer. Respective secondary antibodies were diluted in TBS-Tween $0.5 \%$, added to the membranes, and incubated for $45 \mathrm{~min}$. The measuring of protein signals was performed with chemiluminescence by using the Li-Cor Odissey ${ }^{\circledR}$ Fc Imaging System. Analyses were performed with Image Studio ${ }^{\mathrm{TM}}$ software (version 5.2).

\subsubsection{Quantitative Real-Time RT-PCR}

Total cellular RNA was isolated by using RNeasy kit (Qiagen, Germany). cDNA was synthesized from $1 \mu \mathrm{g}$ of total RNA by using RevertAid $\mathrm{H}$ Minus M-MLV Reverse Transcriptase (Fermentas, Germany). The following primers were used: human glyceraldehyde 3-phosphate dehydrogenase (GAPDH) forward (5'-GCAAATTCCATGGCACCGT-3') and reverse (5'-GCCCCACTTGATTTGGAGG-3'); IAV nucleoprotein (NP) vRNA forward (5'-GGCCGTCAT GGTGGCGAATGAATGGACGGAGAACAAGGATTGC-3') and reverse (5'-CTCAAT ATGAGTGCAGACCGTGCT-3'); cRNA forward (5'-CGATCGTGCCCTCCTTTG-3') and reverse (5'-GCTAGCTTCAGCTAGGCATCAGTAGAAACAAGGGTATTTTTCTTT-3'); mRNA forward (5'-C GATCGTGCCCTCCTTTG-3') and reverse (5'-CCAGATCGTTCGAGTCGTTTTTTTTTTTTTTTT 
TCTTTAATTGTC-3'); IAV matrix protein 1 (M1) vRNA forward (5'-GGCCGTCATGGTG GCGAATTGCAGGGAAGAACACCGATC-3') and reverse (5'-CGTGAACACAAATCCTAA AAT-3'); cRNA forward (5'-AGGGAAGAATATCGAAAGGAAC-3') and reverse (5'-GCTAGCTTCAGCTAGGCAT CAGTAGAAACAAGGTAGTTTTTTAC-3'); mRNA forward (5' - TCCTAGCTCCAGTGCTGGTC-3') and reverse (5'-CCAGATCGTTCGAGTCGTTTTTTTTTTTTTCATTG-3') [70]. qRT-PCR was performed by using QuantiTect SYBR Green PCR kit (Qiagen, Hilden, Germany) [71], and data were acquired with LightCycler 480 Instrument II (Roche, Gruyère, Switzerland). Gene expression was normalized to the endogenous housekeeping control gene GAPDH and analyzed by using $2-\Delta \Delta C T$ method [72].

\subsubsection{Reporter Gene Assay}

This assay followed the procedures described by Schräder et al. [73]. Briefly, MDCK cells grown overnight in 12-well plates were transfected with a transfection mixture containing plasmids encoding PB1, PB2, PA, and NP, a polymerase I (Pol I)-driven plasmid transcribing an influenza A virus-like RNA coding for the reporter protein firefly luciferase to monitor viral polymerase activity. The transfection mixture also contained a plasmid pHW72-Luci carrying a luciferase gene in negative orientation flanked by the viral promoter sequences, which served to normalize variation in transfection efficiency. Medium was changed $4 \mathrm{~h}$ post-transfection (p.t.), C10 and C11 were added at 0.5 and $1.0 \mu \mathrm{M}$ and incubated. Cells were lysed 24 h p.t. and luciferase activity was measured using Dual-Glo Luciferase Assay System (Promega, Madison, WI, USA). PB2 was omitted from the transfection mixture as a negative control. Relative light units (RLU) were normalized to protein concentrations determined with a standard Bradford assay [74], and the relative polymerase activity was depicted as fold induction with respect to MOCK positive control.

\subsubsection{Virus Infection of Human Lung Tissue Explants}

This assay was conducted as described by Matos et al. [53] and the ethical approval was given by the Ethical Council of the Deutsche Ärztekammer (AZ: 2016-265-f-S). Firstly, tumor-free human lung tissue explants were obtained from patients undergoing lung surgery at the University Hospital Muenster, Germany. All patients have given their written consent. Pieces of lung tissue were recovered in Roswell Park Memorial Institute (RPMI-1640) medium on the day of surgery, and stored at $4{ }^{\circ} \mathrm{C}$. Immediately after, tissues were cut in pieces of approximately $100 \mathrm{mg}$, transferred to 12-well plates containing medium and incubated overnight at $37^{\circ} \mathrm{C}$ with $5 \% \mathrm{CO}_{2}$. Then, tissue fragments were infected with recombinant IAV (A/Panama/2007/1999 (H3N2)) in the presence of RPMI-1640 medium (supplemented with $2 \mathrm{mM} \mathrm{L}$-Glutamine, $1 \% \mathrm{P} / \mathrm{S}$ and $0.1 \% \mathrm{BSA}$ ). After $60 \mathrm{~min}$, tissues were transferred to new 12-well-plates with medium containing $\mathbf{C 1 0}$ and $\mathbf{C 1 1}$, at $0.5,1.0$, and $2.0 \mu \mathrm{M}$, and were incubated for $48 \mathrm{~h}$. Supernatants were collected at 1, 24, and $48 \mathrm{~h}$ post-infection (p.i.), and stored at $-80^{\circ} \mathrm{C}$ for viral titer determination using plaque standard assay on MDCK cells $[67,68]$.

\subsection{Statistical Analyses}

The mean values \pm standard deviations $(\mathrm{SD})$ are representative of three or more independent experiments. For the determination of $\mathrm{IC}_{50}$ values, nonlinear regression of concentration-response curves was used. Statistical analyses were performed by ANOVA followed by post hoc tests as indicated. All analyses were performed by using GraphPad Prism 7.00 Software, La Jolla, CA, EUA.

\section{Conclusions}

The semisynthetic derivatives of digitoxigenin $\mathrm{C} 10$ and $\mathrm{C} 11$ showed anti-IAV action by affecting transcription of viral mRNA and thereby altering expression of viral proteins at early stages of the replication cycle, leading to impaired formation of new virions. Such antiviral action occurred due to the interference with the assembly of the viral polymerase complex, resulting in a deficient polymerase activity and, therefore, reducing viral replication. Attesting all these results obtained in vitro, a clinically relevant model of influenza infection by using ex vivo human tumor-free explant 
lung tissue confirmed the potential of these compounds to completely abrogate influenza A virus replication at the highest concentration tested $(2 \mu \mathrm{M})$ at $48 \mathrm{~h}$, mainly for $\mathbf{C 1 0}$. In conclusion, our findings suggest that by their promising and pioneer results, C10 and C11 can be considered as potential anti-influenza drug candidates.

Supplementary Materials: The following are available online, Figure S1: Antiviral activity of new cardenolide derivatives C7c, C10, C11 and C12 and digitoxigenin against distinct Influenza A and B Virus strains, at $1 \mu \mathrm{M}$. ${ }^{* *} p<0.01,{ }^{* * *} p<0.001$ and ${ }^{* * * *} p<0.0001$ vs DMSO, one-way ANOVA, post-hoc test Dunnet; Figure S2: Viability of human tumor-free lung explants after treatment with C10 and C11. Lung tissue explants were treated and their viability over time was assessed by measuring LDH release in culture supernatants, which were collected at the indicated time points. Results are presented as Optical Densities at $450 \mathrm{~nm}$ and have been corrected according to the individual weights of the tissue fragments $(\mathrm{mg})$. The experiment was repeated with lung tissues derived from four independent donors. Each time point represents mean ( $(\mathrm{SEM})$. DMSO served as solvent control. ${ }^{*} p<0.05 \mathrm{vs}$ MOCK, one-way ANOVA, post-hoc test Dunnet.

Author Contributions: Conceptualization, L.B. (Laurita Boff), A.S., C.M.O.S. and S.L.; methodology, L.B. (Laurita Boff), A.S., A.d.R.M., J.D.S., L.B. (Linda Brunotte), J.M., F.M.O., G.S.R., W.K., F.C.B., R.J.A., R.M.d.P., C.M.O.S. and S.L.; software, L.B. (Laurita Boff) and A.S.; validation, L.B. (Laurita Boff), A.S., C.M.O.S. and S.L.; formal analysis, L.B. (Laurita Boff), A.S., C.M.O.S. and S.L.; investigation, L.B. (Laurita Boff) and A.S.; resources, W.K., C.M.O.S. and S.L.; data curation, L.B. (Laurita Boff) and A.S.; writing-original draft preparation, L.B. (Laurita Boff); writing-review and editing, C.M.O.S. and S.L.; visualization, L.B. (Laurita Boff), A.S., C.M.O.S. and S.L.; supervision, C.M.O.S. and S.L.; project administration, C.M.O.S. and S.L.; funding acquisition, W.K., C.M.O.S. and S.L. All authors have read and agreed to the published version of the manuscript.

Funding: The authors thank the Brazilian funding agencies CAPES (MEC) and CNPq (MCTI) for their research fellowships, especially that of L.B. (Laurita Boff) (CNPq grant number 200574/2018-3 of her one-year scholarship at the University of Münster, Germany), and CNPq for the financial support (grant number 305878/2016-6). The German authors from University of Münster thank the German Research Foundation (DFG) for financial support (grants SFB1009B02, LU477/23-1, BR 5189/1-1, KFO324) as well as the Innovative Medizinische Forschung (IMF) and the Interdisciplinary Center for Clinical Research, Münster, which were granted to L.B. Those from Friedrich-Alexander-Universitity Erlangen-Nuremberg thank BAYLAT (JM and RMP for mobility support) and Marie Curie Foundation/European Community (FP7 IRSES, grant 295251, WK).

Conflicts of Interest: The authors declare that they have no conflict of interest.

\begin{tabular}{ll}
\multicolumn{2}{l}{ Abbreviations } \\
A549 & human alveolar epithelial cells \\
CC $_{50}$ & $50 \%$ cytotoxic concentration \\
DMEM & Dulbecco's modified eagle's medium \\
DMSO & dimethyl sulfoxide \\
FBS & fetal bovine serum \\
HA & hemagglutinin \\
IC 50 & concentration required for 50\% inhibition of viral replication \\
IAV & Influenza A virus \\
IBV & Influenza B virus \\
MDCK-II & Madin-Darby canine kidney type II cells \\
MEM & eagle's minimum essential medium \\
MOI & multiplicity of infection \\
NA & neuraminidase \\
PBS & phosphate-buffered saline \\
PFU & plaque-forming units \\
p.i. & post-infection \\
p.t. & post-transfection \\
RIPA & radioimmunoprecipitation \\
RLU & relative light units \\
RPMI-1640 & Roswell Park Memorial Institute-1640 \\
SI & selectivity index \\
WB & western blotting \\
\end{tabular}




\section{References}

1. World Health Organization (WHO). Influenza (Seasonal). Available online: https://www.who.int/en/newsroom/fact-sheets/detail/influenza-(seasonal) (accessed on 7 September 2020).

2. Bush, R.M. Influenza Evolution. In Encyclopedia of Infectious Diseases; Tibayrenc, M., Ed.; Wiley: Hoboken, NJ, USA, 2007; pp. 199-214.

3. Su, S.; Fu, X.; Li, G.; Kerlin, F.; Veit, M. Novel Influenza D virus: Epidemiology, pathology, evolution and biological characteristics. Virulence 2017, 8, 1580-1591. [CrossRef] [PubMed]

4. Behrens, G.; Stoll, M. Pathogenesis and immunology. In Influenza reports 2006; Kamps, B.S., Hoffmann, C., Preiser, W., Eds.; Flying Publisher: Paris, France, 2006; pp. 92-109.

5. Shaw, M.L.; Palese, P. Orthomyxoviridae. In Fields Virology, 6th ed.; Knipe, D.M., Howley, P.M., Cohen, J.I., Griffin, D.E., Lamb, R.A., Martin, M.A., Racaniello, V.R., Roizman, B., Eds.; Lippincott Williams \& Wilkins: Philadelphia, PA, USA, 2013; pp. 1151-1185.

6. Lo, C.-Y.; Tang, Y.-S.; Shaw, P.-C. Structure and Function of Influenza Virus Ribonucleoprotein. Subcell. Biochem. 2018, 88, 95-128. [CrossRef] [PubMed]

7. Dou, D.; Revol, R.; Östbye, H.; Wang, H.; Daniels, R. Influenza A Virus Cell Entry, Replication, Virion Assembly and Movement. Front. Immunol. 2018, 9, 1581. [CrossRef] [PubMed]

8. Carrat, F.; Flahault, A. Influenza vaccine: The challenge of antigenic drift. Vaccine 2007, 25, 6852-6862. [CrossRef]

9. Soema, P.C.; Kompier, R.; Amorij, J.-P.; Kersten, G.F. Current and next generation influenza vaccines: Formulation and production strategies. Eur. J. Pharm. Biopharm. 2015, 94, 251-263. [CrossRef]

10. Principi, N.; Camilloni, B.; Alunno, A.; Polinori, I.; Argentiero, A.; Esposito, S. Drugs for Influenza Treatment: Is There Significant News? Front. Med. 2019, 6, 109. [CrossRef]

11. World Health Organization (WHO). Influenza Vaccine Viruses and Reagents. Available online: https: //www.who.int/influenza/vaccines/virus/en/2020 (accessed on 8 September 2020).

12. Chua, J.V.; Chen, W.H. Bench-to-bedside review: Vaccine protection strategies during pandemic flu outbreaks. Crit. Care 2010, 14, 218. [CrossRef]

13. Hurt, A.C.; Hardie, K.; Wilson, N.J.; Edeng, Y.-M.; Osbourn, B.M.; Gehrig, N.; Kelso, A. Community Transmission of Oseltamivir-Resistant A(H1N1)pdm09 Influenza. N. Engl. J. Med. 2011, 365, 2541-2542. [CrossRef]

14. Takashita, E.; Ejima, M.; Itoh, R.; Miura, M.; Ohnishi, A.; Nishimura, H.; Odagiri, T.; Tashiro, M. A community cluster of influenza A(H1N1)pdm09 virus exhibiting cross-resistance to oseltamivir and peramivir in Japan, November to December 2013. Eurosurveillance 2014, 19, 20666. [CrossRef]

15. Jacob, A.; Sood, R.; Chanu, K.V.; Bhatia, S.; Khandia, R.; Pateriya, A.; Nagarajan, S.; Dimri, U.; Kulkarni, D. Amantadine resistance among highly pathogenic avian influenza viruses (H5N1) isolated from India. Microb. Pathog. 2016, 91, 35-40. [CrossRef]

16. Takashita, E.; Ejima, M.; Ogawa, R.; Fujisaki, S.; Neumann, G.; Furuta, Y.; Kawaoka, Y.; Tashiro, M.; Odagiri, T. Antiviral susceptibility of influenza viruses isolated from patients pre- and post-administration of favipiravir. Antivir. Res. 2016, 132, 170-177. [CrossRef] [PubMed]

17. Matos, A.D.R.; Resende, P.C.; Miranda, M.D.; Garcia, C.C.; Caetano, B.C.; Lopes, J.C.; Debur, M.C.; Cury, A.L.; Vianna, L.A.; Lima, M.C.; et al. Susceptibility of Brazilian influenza A(H1N1)pdm09 viruses to neuraminidase inhibitors in the 2014-2016 seasons: Identification of strains bearing mutations associated with reduced inhibition profile. Antivir. Res. 2018, 154, 35-43. [CrossRef] [PubMed]

18. Horwood, P.F.; Karlsson, E.A.; Horm, S.V.; Ly, S.; Heng, S.; Chin, S.; Darapheak, C.; Saunders, D.; Chanthap, L.; Rith, S.; et al. Circulation and characterization of seasonal influenza viruses in Cambodia, 2012-2015. Influ. Other Respir. Viruses 2019, 13, 465-476. [CrossRef] [PubMed]

19. Leneva, I.; Burtseva, E.; Yatsyshina, S.; Fedyakina, I.; Kirillova, E.; Selkova, Е.; Osipova, Е.; Малеев, В. Virus susceptibility and clinical effectiveness of anti-influenza drugs during the 2010-2011 influenza season in Russia. Int. J. Infect. Dis. 2016, 43, 77-84. [CrossRef]

20. Pshenichnaya, N.Y.; Bulgakova, V.A.; Lvov, N.I.; Poromov, A.A.; Selkova, E.P.; Grekova, A.I.; Shestakova, I.V.; Maleev, V.V.; Leneva, I.A. Clinical efficacy of umifenovir in influenza and ARVI (study ARBITR). Ther. Arch. 2019, 91, 56-63. [CrossRef] 
21. Furuta, Y.; Komeno, T.; Nakamura, T. Favipiravir (T-705), a broad spectrum inhibitor of viral RNA polymerase. Proc. Jpn. Acad. Ser. B 2017, 93, 449-463. [CrossRef]

22. Noshi, T.; Kitano, M.; Taniguchi, K.; Yamamoto, A.; Omoto, S.; Baba, K.; Hashimoto, T.; Ishida, K.; Kushima, Y.; Hattori, K.; et al. In vitro characterization of baloxavir acid, a first-in-class cap-dependent endonuclease inhibitor of the influenza virus polymerase PA subunit. Antivir. Res. 2018, 160, 109-117. [CrossRef]

23. Hoffmann-La Roche (Roche). Roche Announces FDA Approval of Xofluza (Baloxavir Marboxil) for Influenza. Available online: https://www.roche.com/investors/updates/inv-update-2018-10-24.htm (accessed on 7 September 2020).

24. Kreis, W. The Foxgloves (Digitalis) Revisited. Planta Med. 2017, 83, 962-976. [CrossRef]

25. Bessen, H.A. Therapeutic and toxic effects of digitalis: William Withering, 1785. J. Emerg. Med. 1986, 4, 243-248. [CrossRef]

26. Rahimtoola, S.H.; Tak, T. The use of digitalis in heart failure. Curr. Probl. Cardiol. 1996, 21, 781-853. [CrossRef]

27. Patel, S. Plant-derived cardiac glycosides: Role in heart ailments and cancer management. Biomed. Pharmacother. 2016, 84, 1036-1041. [CrossRef] [PubMed]

28. Reddy, D.; Kumavath, R.; Barh, D.; Azevedo, V.; Ghosh, P. Anticancer and Antiviral Properties of Cardiac Glycosides: A Review to Explore the Mechanism of Actions. Molecules 2020, 25, 3596. [CrossRef] [PubMed]

29. Grosso, F.; Stoilov, P.; Lingwood, C.; Brown, M.; Cochrane, A. Suppression of Adenovirus Replication by Cardiotonic Steroids. J. Virol. 2016, 91. [CrossRef] [PubMed]

30. Ashbrook, A.W.; Lentscher, A.J.; Zamora, P.F.; Silva, L.A.; May, N.A.; Bauer, J.A.; Morrison, T.E.; Dermody, T.S. Antagonism of the Sodium-Potassium ATPase Impairs Chikungunya Virus Infection. mBio 2016, 7, e00693-16. [CrossRef]

31. Yang, C.-W.; Chang, H.-Y.; Hsu, H.-Y.; Lee, Y.-Z.; Chang, H.-S.; Chen, I.-S.; Lee, S.-J. Identification of anti-viral activity of the cardenolides, $\mathrm{Na}^{+} / \mathrm{K}^{+}$-ATPase inhibitors, against porcine transmissible gastroenteritis virus. Toxicol. Appl. Pharmacol. 2017, 332, 129-137. [CrossRef]

32. Yang, C.-W.; Chang, H.-Y.; Lee, Y.-Z.; Hsu, H.-Y.; Lee, S.-J. The cardenolide ouabain suppresses coronaviral replication via augmenting a $\mathrm{Na}+/ \mathrm{K}+-\mathrm{ATPase}-$ dependent PI3K_PDK1 axis signaling. Toxicol. Appl. Pharmacol. 2018, 356, 90-97. [CrossRef]

33. Yang, C.-W.; Hsu, H.-Y.; Chang, H.-Y.; Lee, Y.-Z.; Lee, S.-J. Natural cardenolides suppress coronaviral replication by downregulating JAK1 via a $\mathrm{Na}+\mathrm{K}+$-ATPase independent proteolysise. Biochem. Pharmacol. 2020, 180, 114122. [CrossRef]

34. Cai, H.; Wang, H.-Y.L.; Venkatadri, R.; Fu, D.-X.; Forman, M.; Bajaj, S.O.; Li, H.; O’Doherty, G.A.; Arav-Boger, R. Digitoxin Analogues with Improved Anticytomegalovirus Activity. ACS Med. Chem. Lett. 2014, 5, 395-399. [CrossRef]

35. Cohen, T.; Williams, J.D.; Opperman, T.J.; Sanchez, R.; Lurain, N.S.; Tortorella, D. Convallatoxin-Induced Reduction of Methionine Import Effectively Inhibits Human Cytomegalovirus Infection and Replication. J. Virol. 2016, 90, 10715-10727. [CrossRef]

36. Gardner, T.J.; Cohen, T.; Redmann, V.; Lau, Z.; Felsenfeld, D.; Tortorella, D. Development of a high-content screen for the identification of inhibitors directed against the early steps of the cytomegalovirus infectious cycle. Antivir. Res. 2015, 113, 49-61. [CrossRef]

37. Cheung, Y.Y.; Chen, K.C.; Chen, H.; Seng, E.K.; Chu, J.J.H. Antiviral activity of lanatoside C against dengue virus infection. Antivir. Res. 2014, 111, 93-99. [CrossRef] [PubMed]

38. Bertol, J.W.; Rigotto, C.; De Pádua, R.M.; Kreis, W.; Barardi, C.R.M.; Braga, F.C.; Simões, C.M.O. Antiherpes activity of glucoevatromonoside, a cardenolide isolated from a Brazilian cultivar of Digitalis lanata. Antivir. Res. 2011, 92, 73-80. [CrossRef] [PubMed]

39. Dodson, A.W.; Taylor, T.J.; Knipe, D.M.; Coen, D.M. Inhibitors of the sodium potassium ATPase that impair herpes simplex virus replication identified via a chemical screening approach. Virology 2007, 366, 340-348. [CrossRef] [PubMed]

40. Su, C.-T.; Hsu, J.T.-A.; Hsieh, H.-P.; Lin, P.-H.; Chen, T.-C.; Kao, C.-L.; Lee, C.-N.; Chen, Y.-C. Anti-HSV activity of digitoxin and its possible mechanisms. Antivir. Res. 2008, 79, 62-70. [CrossRef]

41. Boff, L.; Schneider, N.F.Z.; Munkert, J.; Ottoni, F.M.; Ramos, G.S.; Kreis, W.; Braga, F.C.; Alves, R.J.; De Pádua, R.M.; Simões, C.M.O. Elucidation of the mechanism of anti-herpes action of two novel semisynthetic cardenolide derivatives. Arch. Virol. 2020, 165, 1385-1396. [CrossRef] 
42. Singh, S.; Shenoy, S.; Nehete, P.N.; Yang, P.; Nehete, B.; Fontenot, D.; Yang, G.; Newman, R.A.; Sastry, K.J. Nerium oleander derived cardiac glycoside oleandrin is a novel inhibitor of HIV infectivity. Fitoterapia 2013, 84, 32-39. [CrossRef]

43. Wong, R.W.; Balachandran, A.; Ostrowski, M.A.; Cochrane, A. Digoxin Suppresses HIV-1 Replication by Altering Viral RNA Processing. PLoS Pathog. 2013, 9, e1003241. [CrossRef]

44. Wong, R.W.; Lingwood, C.A.; Ostrowski, M.A.; Cabral, T.; Cochrane, A. Cardiac glycoside/aglycones inhibit HIV-1 gene expression by a mechanism requiring MEK1/2-ERK1/2 signaling. Sci. Rep. 2018, 8, 850. [CrossRef]

45. Van Der Kolk, T.; Dillingh, M.; Rijneveld, R.; Klaassen, E.; De Koning, M.; Kouwenhoven, S.; Genders, R.; Bavinck, J.N.B.; Feiss, G.; Rissmann, R.; et al. Topical ionic contra-viral therapy comprised of digoxin and furosemide as a potential novel treatment approach for common warts. J. Eur. Acad. Dermatol. Venereol. 2017, 31, 2088-2090. [CrossRef]

46. Hoffmann, H.-H.; Palese, P.; Shaw, M.L. Modulation of influenza virus replication by alteration of sodium ion transport and protein kinase C activity. Antivir. Res. 2008, 80, 124-134. [CrossRef]

47. Kiyohara, H.; Ichino, C.; Kawamura, Y.; Nagai, T.; Sato, N.; Yamada, H.; Salama, M.M.; Abdel-Sattar, E.A. In vitro anti-influenza virus activity of a cardiotonic glycoside from Adenium obesum (Forssk.). Phytomedicine 2012, 19, 111-114. [CrossRef] [PubMed]

48. Amarelle, L.; Katzen, J.; Shigemura, M.; Welch, L.C.; Cajigas, H.; Peteranderl, C.; Celli, D.; Herold, S.; Lecuona, E.; Sznajder, J.I. Cardiac glycosides decrease influenza virus replication by inhibiting cell protein translational machinery. Am. J. Physiol. Cell. Mol. Physiol. 2019, 316, L1094-L1106. [CrossRef] [PubMed]

49. Norris, M.J.; Malhi, M.; Duan, W.; Ouyang, H.; Granados, A.; Cen, Y.; Tseng, Y.-C.; Gubbay, J.; Maynes, J.; Moraes, T. Targeting Intracellular Ion Homeostasis for the Control of Respiratory Syncytial Virus. Am. J. Respir. Cell Mol. Biol. 2018, 59, 733-744. [CrossRef] [PubMed]

50. Boff, L.; Munkert, J.; Ottoni, F.M.; Schneider, N.F.Z.; Ramos, G.S.; Kreis, W.; Andrade, S.F.; Souza Filho, J.D.; Braga, F.C.; Alves, R.J.; et al. Potential anti-herpes and cytotoxic action of novel semisynthetic digitoxigenin-derivatives. Eur. J. Med. Chem. 2019, 167, 546-561. [CrossRef]

51. Boff, L.; Persich, L.; Brambila, P.; Ottoni, F.M.; Munkert, J.; Ramos, G.S.; Viana, A.R.S.; Kreis, W.; Braga, F.C.; Alves, R.J.; et al. Investigation of the cytotoxic activity of two novel digitoxigenin analogues on H460 lung cancer cells. Anti-Cancer Drugs 2020, 31, 452-462. [CrossRef]

52. Rameix-Welti, M.-A.; Tomoiu, A.; Afonso, E.D.S.; Van Der Werf, S.; Naffakh, N. Avian Influenza A Virus Polymerase Association with Nucleoprotein, but Not Polymerase Assembly, Is Impaired in Human Cells during the Course of Infection. J. Virol. 2008, 83, 1320-1331. [CrossRef]

53. Matos, A.D.R.; Wunderlich, K.; Schloer, S.; Schughart, K.; Geffers, R.; Seders, M.; De Witt, M.; Christersson, A.; Wiewrodt, R.; Wiebe, K.; et al. Antiviral potential of human IFN- $\alpha$ subtypes against influenza A H3N2 infection in human lung explants reveals subtype-specific activities. Emerg. Microbes Infect. 2019, 8, 1763-1776. [CrossRef]

54. Prassas, I.; Diamandis, E.P. Novel therapeutic applications of cardiac glycosides. Nat. Rev. Drug Discov. 2008, 7, 926-935. [CrossRef]

55. Amarelle, L.; Lecuona, E. The Antiviral Effects of Na,K-ATPase Inhibition: A Minireview. Int. J. Mol. Sci. 2018, 19, 2154. [CrossRef]

56. Hui, E.K.-W.; Nayak, D.P. Role of ATP in Influenza Virus Budding. Virology 2001, 290, 329-341. [CrossRef]

57. Ishihama, A. A multi-functional enzyme with RNA polymerase and RNase activities: Molecular anatomy of influenza virus RNA polymerase. Biochimie 1996, 78, 1097-1102. [CrossRef]

58. Honda, A.; Ishihama, A. The molecular anatomy of influenza virus RNA polymerase. Biol. Chem. 1997, 378, 483-488. [PubMed]

59. Kilkenny, C.; Browne, W.; Cuthill, I.C.; Emerson, M.; Altman, D.G. Animal research: Reporting in vivo experiments: The ARRIVE guidelines. Br. J. Pharmacol. 2010, 160, 1577-1579. [CrossRef] [PubMed]

60. Perne, A.; Muellner, M.K.; Steinrueck, M.; Craig-Mueller, N.; Mayerhofer, J.; Schwarzinger, I.; Sloane, M.; Uras, I.Z.; Hoermann, G.; Nijman, S.M.B.; et al. Cardiac Glycosides Induce Cell Death in Human Cells by Inhibiting General Protein Synthesis. PLoS ONE 2009, 4, e8292. [CrossRef] [PubMed]

61. Calderón-Montaño, J.M.; Burgos-Morón, E.; Orta, M.L.; Maldonado-Navas, D.; García-Domínguez, I.; Lopez-Lazaro, M. Evaluating the Cancer Therapeutic Potential of Cardiac Glycosides. BioMed Res. Int. 2014, 2014, 1-9. [CrossRef] 
62. Weinheimer, V.K.; Becher, A.; Tönnies, M.; Holland, G.; Knepper, J.; Bauer, T.T.; Schneider, P.; Neudecker, J.; Rückert, J.C.; Szymanski, K.; et al. Influenza A Viruses Target Type II Pneumocytes in the Human Lung. J. Infect. Dis. 2012, 206, 1685-1694. [CrossRef] [PubMed]

63. Yang, J.; Du, J.; Huang, C.; Wang, T.; Huang, L.; Yang, S.; Li, L. Discovery of 5-(5-fluoro-1H-pyrrolo [2,3-b]pyridin-3-yl)pyrazin-2(1H)-one derivatives as new potent PB2 inhibitors. Bioorganic Med. Chem. Lett. 2019, 29, 1609-1613. [CrossRef]

64. Zhao, X.; Wang, Y.; Cui, Q.; Li, P.; Wang, L.; Chen, Z.; Rong, L.; Du, R. A Parallel Phenotypic Versus Target-Based Screening Strategy for RNA-Dependent RNA Polymerase Inhibitors of the Influenza A Virus. Viruses 2019, 11, 826. [CrossRef]

65. Zhang, J.; Hu, Y.; Wu, N.; Wang, J. Discovery of Influenza Polymerase PA-PB1 Interaction Inhibitors Using an In Vitro Split-Luciferase Complementation-Based Assay. ACS Chem. Biol. 2019, 15, 74-82. [CrossRef]

66. Hoffmann, E.; Neumann, G.; Kawaoka, Y.; Hobom, G.; Webster, R.G. A DNA transfection system for generation of influenza A virus from eight plasmids. Proc. Natl. Acad. Sci. USA 2000, 97, 6108-6113. [CrossRef]

67. Burleson, F.G.; Chamberts, T.M.; Wiedbrauk, D.L. Virology: A Laboratory Manual; Academic Press: San Diego, CA, USA, 1992; p. 250.

68. Dudek, S.E.; Luig, C.; Pauli, E.-K.; Schubert, U.; Ludwig, S. The Clinically Approved Proteasome Inhibitor PS-341 Efficiently Blocks Influenza A Virus and Vesicular Stomatitis Virus Propagation by Establishing an Antiviral State. J. Virol. 2010, 84, 9439-9451. [CrossRef] [PubMed]

69. Schreiber, A.; Liedmann, S.; Brunotte, L.; Anhlan, D.; Ehrhardt, C.; Ludwig, S. Type I interferon antagonistic properties of influenza B virus polymerase proteins. Cell. Microbiol. 2019, 22, e13143. [CrossRef]

70. Kawakami, E.; Watanabe, T.; Fujii, K.; Goto, H.; Watanabe, S.; Noda, T.; Kawaoka, Y. Strand-specific real-time RT-PCR for distinguishing influenza vRNA, cRNA, and mRNA. J. Virol. Methods 2011, 173, 1-6. [CrossRef]

71. Börgeling, Y.; Schmolke, M.; Viemann, D.; Nordhoff, C.; Roth, J.; Ludwig, S. Inhibition of p38 Mitogen-activated Protein Kinase Impairs Influenza Virus-induced Primary and Secondary Host Gene Responses and Protects Mice from Lethal H5N1 Infection. J. Biol. Chem. 2013, 289, 13-27. [CrossRef]

72. Liu, W.; Saint, D.A. A New Quantitative Method of Real Time Reverse Transcription Polymerase Chain Reaction Assay Based on Simulation of Polymerase Chain Reaction Kinetics. Anal. Biochem. 2002, 302, 52-59. [CrossRef]

73. Schräder, T.; Dudek, S.E.; Schreiber, A.; Ehrhardt, C.; Planz, O.; Ludwig, S. The clinically approved MEK inhibitor Trametinib efficiently blocks influenza A virus propagation and cytokine expression. Antivir. Res. 2018, 157, 80-92. [CrossRef]

74. Bradford, M.M. A rapid and sensitive method for the quantitation of microgram quantities of protein utilizing the principle of protein-Dye binding. Anal. Biochem. 1976, 72, 248-254. [CrossRef]

Sample Availability: Samples of the compounds C6a, C6b, C6c, C6d, C7a, C7b, C7c, C7d, C9, C10, C11, C12, C13, C14, C15, and C16 are available from the authors.

Publisher's Note: MDPI stays neutral with regard to jurisdictional claims in published maps and institutional affiliations.

(C) 2020 by the authors. Licensee MDPI, Basel, Switzerland. This article is an open access article distributed under the terms and conditions of the Creative Commons Attribution (CC BY) license (http://creativecommons.org/licenses/by/4.0/). 